\title{
Dolmányos varjak (Corvus cornix Linnaeus, 1758) szárnybilétás jelölése Debrecenben
}

\author{
Paládi Petra ${ }^{1}$, Tóth Dávid ${ }^{1}$, Lengyel Szabolcs ${ }^{2}$, Juhász Lajos ${ }^{1}$ és \\ Kövér László ${ }^{1}$ \\ ${ }^{1}$ Debreceni Egyetem, Mezőgazdaság-, Élelmiszertudományi és Környezetgazdálkodási \\ Kar, Természetvédelmi Állattani és Vadgazdálkodási Tanszék, \\ 4032 Debrecen, Böszörményi út 138. \\ ${ }^{2}$ Magyar Tudományos Akadémia, Ökológiai Kutatóközpont, Duna-kutató Intézet, Tisza- \\ kutató Osztály, \\ 4026 Debrecen, Bem tér 18/C \\ e-mail:paladi17@gmail.com
}

Összefoglaló: A Debreceni Egyetem Mezőgazdaság-, Élelmiszertudományi és Környezetgazdálkodási Kar Természetvédelmi Állattani és Vadgazdálkodási Tanszéke 2006 óta foglalkozik városi környezetben előforduló varjúfélékkel, kiemelt figyelmet fordítva a dolmányos varjúra (Corvus cornix L. 1758), amely jelentős állománynövekedése számos problémát okoz mind a városi madárfauna (pl. fészekfosztogatás), mind a lakosság szempontjából (zajongás, rongálás, agresszió). Mindezek tükrében elképzelhető, hogy a jövőben szükségessé válhat városi állományszabályozásuk, amelyre megoldást különböző élvefogó ládacsapdák alkalmazása jelenthet. A Tanszéken 2016 novemberében elindult egy csapdázási kísérlet, melynek célja egyrészt a varjúfélék esetében releváns csapdatípusok (létrás csapda, Larsen csapda, svéd csapda) hatékonyságának vizsgálata, másrészt a csapdázás során befogott madarak egyedileg történő megjelölése, majd nyomon követése volt. Utóbbi célja, hogy többet megtudjunk a varjak városon belüli mozgásáról, területhűségéról, túléléséről. A dolmányos varjak esetében a jelölés egyedi sorszámmal ellátott szárnybilétákkal történt. A bilétákat a szárny patagium részébe rögzítettük juhoknál alkalmazott füljelző krotáliák segítségével. A több mint 100 csapdanap alatt 28 dolmányos varjat fogtunk, továbbá jelentôs számú vetési varjú (Corvus frugilegus L. 1758) is a csapdáinkba került. A 28 jelölt dolmányos varjú közül novembertől márciusig terjedő időszakban 26 egyedröl több mint 250 visszajelzést kaptunk. Előzetes eredményeink alapján a dolmányos varjak területhüek, mivel az észlelések szinte minden esetben a gyürüzés helyének közvetlen környezetéből származtak. A legtávolabbi visszajelzés 4 km-ről érkezett. A jelölt varjak gyakran tünnek fel csoportosan, volt rá példa, hogy 16 szárnybilétás egyed egy időben tartózkodott egy helyen. A szárnybilétás jelölés hatékonynak bizonyul, mivel a bilétás egyedek nagyobb távolságról is könnyen észrevehetők, szemben a csak színes gyürüvel jelölt madarakkal.

Kulcsszavak: dolmányos varjú, Corvus cornix, városi környezet, szárnybiléta, csapdázás 


\section{Bevezetés}

A varjúfélék már az ősi időktől kezdve előfordultak városi környezetben. A 18. és 19. században populációik hanyatlása volt megfigyelhető, a 19. század végétől azonban tendenciózusan nőtt egyedszámuk az urbánus élettereiken (Vrezec 2010). Napjainkban több varjúfaj tekinthető gyakorinak Európai városokban (Vogrin 2003, Mazgajski et al. 2008, Juhász et al. 2009, Kövér et al. 2015). A városiasodás számos tényezővel magyarázható. A települések változatos élőhelyeikkel kiváló életfeltételeket biztosítanak a varjak számára is: úgy, mint megfelelő költőhelyek, állandó táplálékforrások (Vuorisalo et al. 2003). Fontos szempont még, hogy városi környezetben kisebb mértékủ az adult egyedek predációja (Anderies et al. 2007), továbbá egyes urbanizálódott fajok rezisztensek lehetnek különböző parazitákkal szemben is (Møller 2009). A varjúfélék széleskörü elterjedése és nagymértékű városiasodása köszönhető továbbá kiemelkedő alkalmazkodóképességüknek, ökológiai rugalmasságuknak (Emery \& Clayton 2004, Kövér et al. 2015). A dolmányos varjú debreceni fészkeléséről 1959 óta beszélhetünk (Juhász 1983), ezután azonban közel 20 évig nem történt költési próbálkozás. 1972-ben (Fintha 1994), majd 1979-ben jelent meg újra, azóta pedig általánosan előforduló, állandóan jelenlévő költőfajnak tekinthető (Juhász et al. 2009).

A DE MÉK Természetvédelmi Állattani és Vadgazdálkodási Tanszéken az utóbbi években többrétủ kutatás folyik a fajjal kapcsolatban; ilyen például a fészek-monitoring (Kövér et al. 2015), a színes gyürüs jelölési program (Kövér \& Juhász 2012), 2014 óta pedig egy csapdázási kísérlet is elindult (Kövér et al. 2017, in press). A nyolc éven keresztül folyó fészkelö-állomány felméréséből kiderült, hogy a városban élő dolmányos varjak száma az elmúlt évtizedben drasztikusan növekedett, amely számos problémát vet fel mind a városi fauna, mind a lakosság tekintetében. Más madarak fészekaljait rabolják ki (Amar \& Burthe 2001), fészkükből kirepült fiókákat is zsákmányolhatnak, sőt az is előfordult már, hogy a varjak összehangoltan zsákmányoltak parlagi galambokat (Köszegfalvi 2008). Problémát okozhat még zajongásuk (Raatikainen et al. 1989), rongálásuk, esetleges kórokozók terjesztésében betöltött szerepük (Gremmel 1988), továbbá egyre gyakrabban előforduló agresszív viselkedésük is. Mindezek tükrében indokolt a faj egyre szélesebb körü tanulmányozása mind életmód, mind pedig terjeszkedés szempontjából, emellett elképzelhető, hogy a dolmányos varjak városi állományszabályozására is szükség lehet.

Fent említettekhez járul hozzá a Tanszék 2016 őszén újraindult csapdázási kísérlete. Ennek egyik célja a különböző típusú élvefogó ládacsapdák sikerességének vizsgálata városi környezetben. A varjak gyakran különböző kutatások alanyai - pl. etológiai (Holzhaider et al. 2011) -, ezért sikeres csapdázásuk, egyedi jelölésük és vizsgálatuk kiemelkedő fontosságú. Az élvefogó csapdák alkal- 
mazása a városi állományszabályozás egyik módja is lehet. A varjak befogása azonban nehéz feladat, köszönhetően a varjúfélék nagymértékü intelligenciájának (Bub 1995). Jelen kutatás egy módszercsalád első hazai alkalmazása a dolmányos varjakon, eredményességének tesztelése. Az eredmények mind a természetvédelemben, mind a városi vadgazdálkodásban felhasználhatók.

A kutatás másik célkitüzése a dolmányos varjak városon belüli mozgásának, területhűségének tanulmányozása, melyekről jelenleg kevés információ áll rendelkezésünkre. A madarak mozgásmintázatának felméréséhez elengedhetetlen az egyedileg történő megjelölésük, majd a jelölt egyedek elöre meghatározott metodika alapján történő nyomon követése.

\section{Módszerek}

\section{Csapdázás}

A csapdázási kísérlet 4 hónapon keresztül, 2016 novembertől 2017 február végéig tartott. Helyszínül a Debreceni Egyetem Böszörményi úti Campusának területe szolgált, ahol nagy számban figyelhetünk meg különböző varjúféléket: dolmányos varjú, szarka (Pica pica L. 1758), szajkó (Garrulus glandarius L. 1758), téli időszakban pedig jelentős a vetési varjak száma. A Campus hátsó, emberi zavarástól és forgalomtól kevésbé érintett része kiváló helyszínt biztosított a csapdázáshoz (1. ábra). Itt található például a Campus botanikus kertje, a Farmer Expo megrendezésére szolgáló nagy kiterjedésü füves terület és több kisebb, körbekerített egység, mint a Kertészet területe is. Csapdaparkunk hét, varjúfélék esetében releváns csapdából állt: egy létrás csapdából, két svéd csapdából, továbbá két Larsen- oldalajtós és két Larsen- felsőajtós csapdából (1. függelék az Online Függelékben $[\mathrm{OF}])$. Az általunk épített létrás csapda $2 \times 2 \times 2,5$ méteres méretekkel rendelkezett, a beugró nyílás $20 \times 16 \mathrm{~cm}$-es volt. A Larsen csapdák standard méretüek $(80 \times 80 \times 50 \mathrm{~cm})$ voltak, csakúgy, mint a svéd csapdák. A csapdák egymástól kb. 25 méterre lettek elhelyezve. A létrás csapda helye állandó volt, a ládacsapdák azonban hetente rotálva lettek. A csapdák csalifalatokkal (kenyér) voltak ellátva, ezenkívül a létrás csapdába, illetve minden páros csapda egyikébe csalimadár (dolmányos varjú) is került (2. ábra). A csapdák ellenőrzése, továbbá a csalimadarak élelemmel és friss vízzel való ellátása minden esetben sötétedés után történt, így elkerülve azt, hogy a varjak összekössék a csapdákat az emberrel. A befogott egyedek az éjszakát zsákokban, védett helyen töltötték, mert a nappali elengedésük biztonságosabb. A csapdázást követő napon a madarak biometriai adatfelvételezése (pl. tömeg, testhossz, fejhossz, csőrhossz, stb.) után egyedileg kerültek megjelölésre, majd pedig elengedésre. 


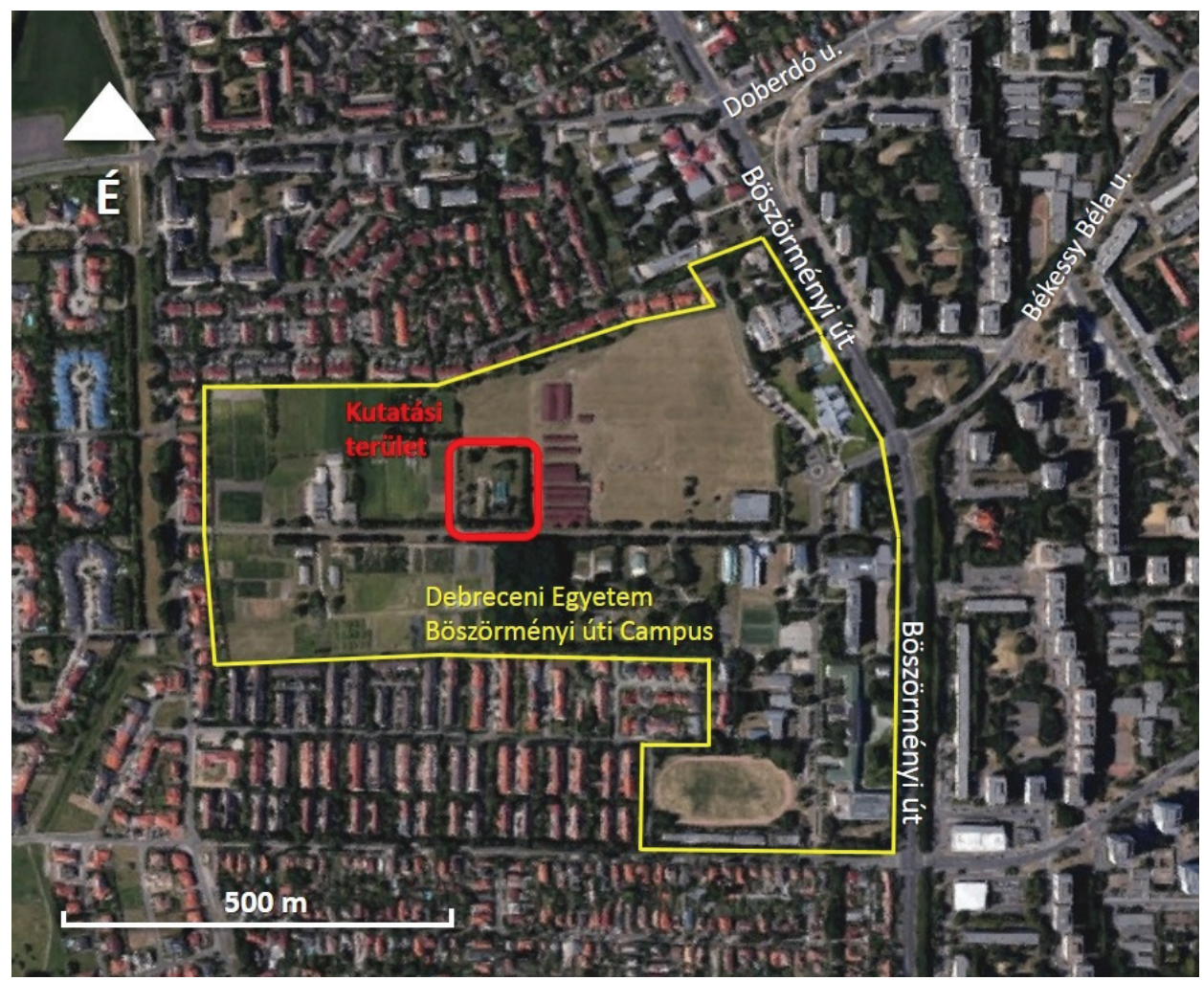

1. ábra. A csapdázás helyszíne a Debreceni Egyetem Böszörményi úti Campusa területén.

\section{Jelölés}

Minden dolmányos varjú bal csüdjére hagyományos alumínium gyürü, a jobbra pedig fehér müanyag gyürü került. Ezenkívül minden madár szárnybilétát is kapott (2. függelék az Online Függelékben [OF]). A jelölés ezen típusa hatékonyabb a színes gyürüs jelöléssel szemben, mivel a bilétával jelölt madarak nagy távolságról is észrevehetök és egyedileg beazonosíthatók. A színes gyürüket sok esetben még távcsővel sem lehet leolvasni. A szárnybiléták alkalmazása tartósabb, megfelelöen felhelyezve minimális a bilétaveszteség, míg a színes gyürüket a madarak gyakran elhagyják, leszedik. Számos faj esetében történt már szárnybilétás jelölés, többek között kistestü énekesmadaraknál, mint rigók, seregélyek vagy szajkók (Hester 1963), gatyás ölyveknél (Watson 1985), szirti sasoknál (Phillips et al. 1991), vagy keselyüknél (Wallace et al. 1980, Sweeney et al. 1985, Reading et al. 2014). Magyarországon Dr. Tóth László alkalmazza ezt a módszert barna rétihéjáknál (Tóth 2006). A szárnybilétával történő jelölés negatív hatásairól nincsenek közlések, tapasztalatok; vélhetően minimális, ugyanis nem befolyásolják a 


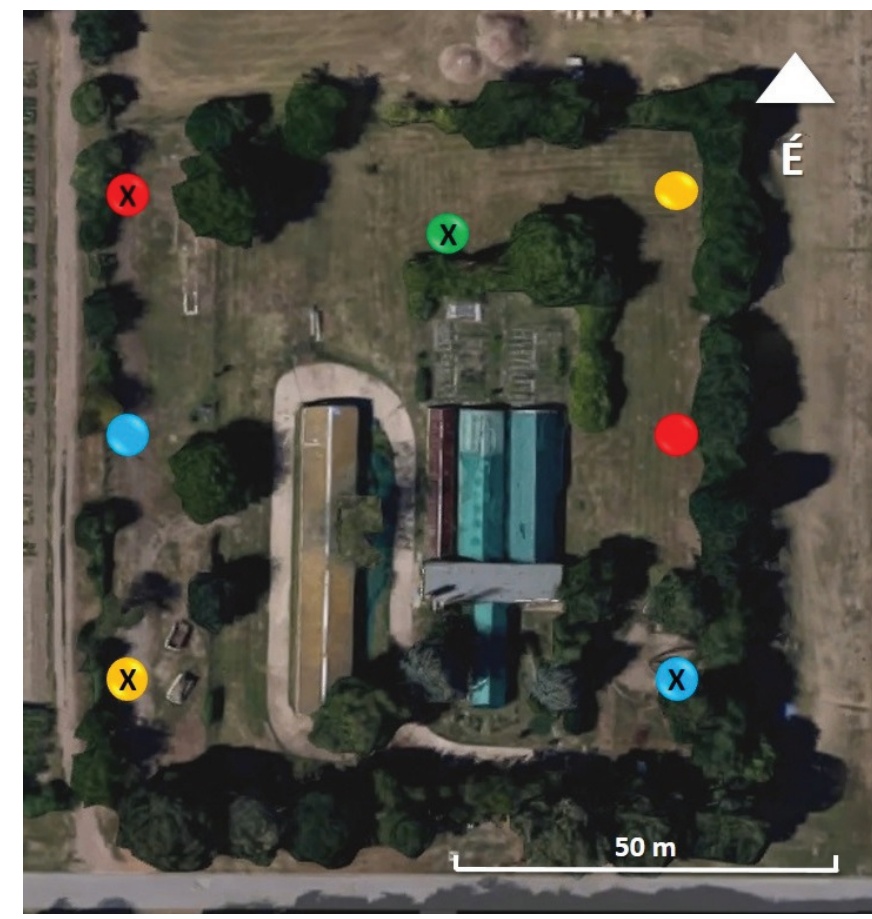

- Svéd csapda

- Larsen csapda (oldalajtós)

- Larsen csapda (felsőajtós)

- Létrás csapda

X: csalimadár

2. ábra. A csapdák elhelyezkedése a csapdázási területen

repülést, az egyedek viselkedését, nem okoznak sérülést, felhelyezésük nem okoz fájdalmat sem. Varjúfélék esetében is használták már a jelölés ezen fajtáját, például hollóknál (Stiehl 1983, Loretto et al. 2015), és rövidcsőrü varjaknál (Caffrey 2000). A biléták felhelyezése több módon történhet. Egyik lehetőség a biléta humerus köré történő rögzítése (Morgenweck \& Marshall 1977). Ennek hátránya, hogy kevésbé tartós, lazán felhelyezve elfordulhat a szárny körül, túl szorosan pedig duzzanatot okozhat (Curtis et al. 1983). Egy másik, gyakrabban alkalmazott módszer a szárnybiléta patagiumon keresztül történő rögzítése (Mudge \& Ferns 1978, Stiehl 1983). A biléta felhelyezésére többféle módszert alkalmaznak: használhatnak például vékony mủanyag húrt (Caffrey 2000), rozsdamentes acél tüt (Mudge \& Ferns 1978), fém szegecseket (Stiehl 1983), vagy különböző füljelző krotáliákat (Reading et al. 2014). A rögzítés ezen típusai sokkal tartósabb jelölést eredményeznek.

Jelen kutatásban a bilétákat Dr. Tóth László (Eszterházy Károly Egyetem) útmutatásai szerint, juhoknál alkalmazott füljelző krotáliák segítségével rögzítettük a patagiumba (Tóth 2006) (3. ábra). 




3. ábra. Szárnybilétával jelölt dolmányos varjú (fotó: Dr. Gyüre Péter). A biléta helye a patagiumban (forrás: Caffrey 2000).

A jelölés során a bal-, illetve a jobb szárnyra is egy-egy fehér színű, egyedi sorszámmal ellátott biléta került (3. függelék az Online Függelékben [OF]). A szárnybiléta $10,5 \times 2,5 \mathrm{~cm}$-es, anyaga fehér ponyvaanyag, amelyre fekete színnel egy kétjegyű szám került. A biléta felhelyezése fájdalommentes, és nem befolyásolja negatívan a madarak repülését. Az EURING színes gyürüs munkacsoportjával az egyeztetés megtörtént, programunk a honlapjukon megtalálható (http:// www.cr-birding.org/node/4350).

\section{Visszakeresés}

Meghatározott útvonalakon megfigyelési pontok kerültek kijelölésre, melyeken hetente többször történik az adatfelvétel. A pontok kijelölésénél a legfőbb szempont az állandó táplálékforrás megléte volt (pl. állatkerti állatok tápláléka, galambok, macskák állandó etetése), amely feltételezi a varjak gyakori megjelenését. Két különböző útvonalat jelöltünk ki: egy rövidebbet, amely a Böszörményi úti Campus környékét fedi le. Itt két pont található, a Kertészet területe, ahol a csapdapark is létesítésre került, továbbá a Farmer Expo helyszínéül szolgáló füves terület. Ezen az útvonalon heti négyszer történik adatfelvétel. A másik, hosszabb $(\sim 10 \mathrm{~km})$ útvonal Debrecen északi városrészében fut: DEAC Sportcentrum, Bé- 
kás-tó, Nagyerdei Kultúrpark (Állatkert), Oláh Gábor utcai sporttelep, továbbá a Debreceni Egyetem Kassai úti Campusa. Itt heti két felmérést végzünk. Az észlelések pontos időpontját, valamint a jelölt madarak GPS koordinátáit minden esetben rögzítjük. A program továbbá a helyi sajtóban, közösségi oldalakon, rádióban is meghirdetésre került, ennek eredményeképpen önkéntesektől is nagy számban érkeznek visszajelzések, sok esetben fotókkal és videókkal.

\section{Előzetes eredmények}

Több, mint 100 csapdanap során 28 dolmányos varjat fogtunk, ezek mindegyike fiatal, 1. éves madár. A dolmányos varjak kora elsősorban a csőr és a nyelv színe alapján határozható meg: fiatal korban ezek döntően rózsaszínủek, a kor előrehaladtával azonban egyre inkább feketévé válnak (O’Donoghue et al. 1998). Mivel nem beszélhetünk látható ivari dimorfizmusról, a madarak nemét a gyürüzés során nem tudtuk megállapítani, erre a későbbiekben kerül sor a biometriai adatfelvétel során vett tollminták vizsgálatával. A dolmányos varjakon kívül több mint 250 vetési varjú, 2 csóka (Corvus monedula L. 1758), 2 szarka, 2 széncinege (Parus major L. 1758), 1 kékcinege (Cyanistes caeruleus L. 1758), 5 feketerigó (Turdus merula L. 1758) és 1 vörös mókus (Sciurus vulgaris L. 1758) is csapdáinkba került. Ezek alapján kijelenthető, hogy a csapdák viszonylag szelektívek és használatuk mindenképpen hatékony módszer varjúfélék befogására városi környezetben. A befogott 28 dolmányos varjú mindegyikére került szárnybiléta, közülük 26 egyedről eddig több mint 250 visszajelzés áll a rendelkezésünkre. Ezek döntő többségét ( 65\%) a városból érkező visszajelzések alkotják, melyek a visszakeresések során gyüjtött adatokból, továbbá az önkéntesektől érkező visszajelzésekből tevődnek össze. Az eddigi adatok alapján elmondható, hogy a dolmányos varjak területhüek, mert a visszajelzések nagy része a gyürüzés helyének közvetlen környezetéből származik. A gyürüzés helyétöl számított legtávolabbi visszajelzés közel 4 km-ről érkezett. A jelölt egyedek leggyakrabban a Böszörményi úti Campus területén, a Doberdó út környékén, illetve a Nagyerdei Kultúrparkban és környékén jelennek meg. A varjak gyakori előfordulása ezeken a területeken az állandó táplálékforrás jelenlétével magyarázható. Gyakran előfordul, hogy a jelölt madarak együtt mozognak. Egy alkalommal a Nagyerdei Stadionnál gyülekező több százas dolmányos varjú csapatban 16 általunk jelölt egyedet számoltunk össze. Ez a csoportos mozgás minden valószínủség szerint meg fog szünni a tavaszi időszakban, amikor az idősebb madarak már párban, revírjüket védelmezve fognak élni. Az is elöfordult, hogy bizonyos egyedek rövid időn belül jelentősebb távolságot tettek meg. Erre jó példa a 21-es számú egyed, 
amely elöször a Tócóskertben tünt fel, majd rövid időt követően az Állatkertnél jelentették, közel 4,5 km-rel távolabb (4. ábra).

A varjak pontos mozgásának felmérésére GPS jeladós jelölés jelentene megoldást, mivel így egzakt módon követhető lenne az egyes egyedek mozgása. A városból érkező visszajelzések mellett csapdával is történtek visszafogások, erre a csapdázás időtartama alatt 9 egyed esetében mintegy 100 alkalommal került sor. Itt említést érdemel egy csapdafüggővé vált madár, amely több mint 30 alkalommal került visszafogásra, szinte kivétel nélkül a létrás csapdából. Ez a viselkedés valószínúleg az állandó táplálék jelenlétével magyarázható.

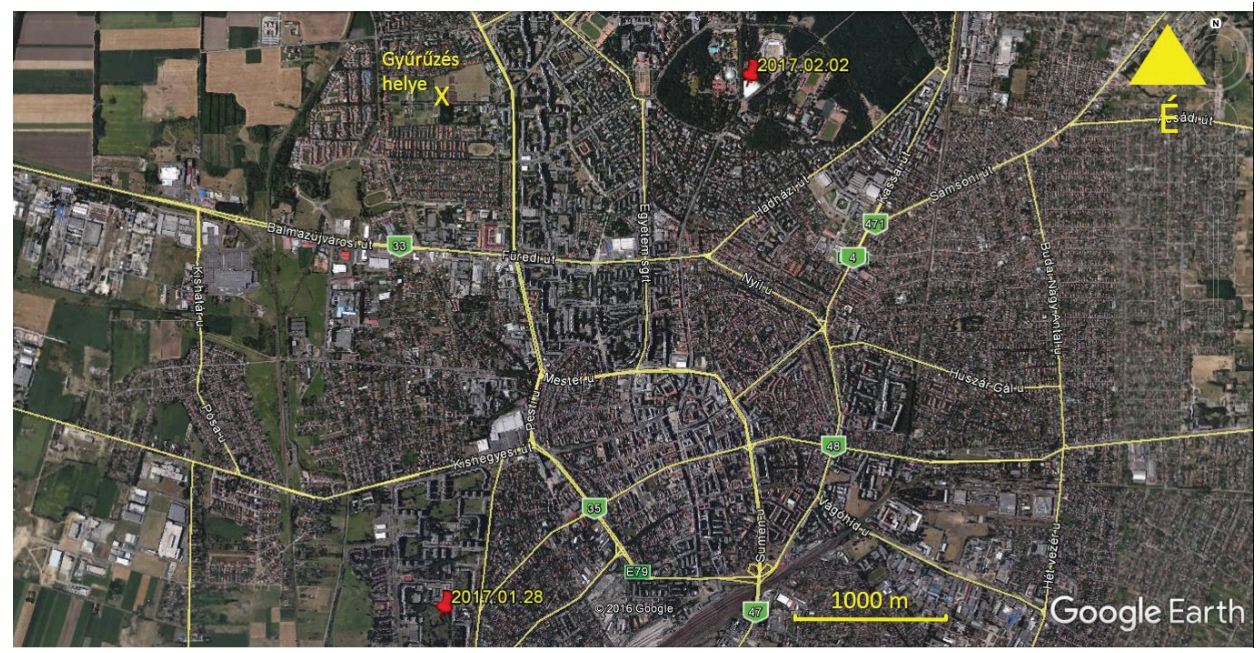

4. ábra. A 21-es egyed mozgása ( $\mathrm{n}=2)$.

\section{Értékelés}

A terepi munkák során tapasztalatokat szereztünk, az elért eredmények kutatásmódszertan tekintetében is jelentősek. Kijelenthető, hogy az élvefogó ládacsapdák használata hatékony módja a varjúfélék befogásának városi környezetben is. A csapdázás február utolsó napjáig tartott, mivel utána kíméleti időszak van a vadászható varjúfajokra, a jelölt egyedek nyomon követése azonban egész évben folytatódik. A tavasz nagy valószínűséggel további érdekességeket hoz, mivel a szaporodási időszakban beállt revírek miatt változni fog madarak mozgásmintázata. 
Előzetes eredményeink alapján megállapítható, hogy a szárnybiléták használata hatékony módja a dolmányos varjak jelölésének, alkalmazásuk eredményes lehet akár más varjúfélék esetében is.

Köszönetnyilvánitás - Ezúton is köszönetünket fejezzük ki Dr. Tóth László tanár úrnak (Eszterházy Károly Egyetem) a szárnybilétás metodika elsajátításában nyújtott segítségéért. Továbbá Dudás Miklósnak, a Hortobágyi Nemzeti Park nyugalmazott természetvédelmi örének hasznos tanácsaiért; Oláh Jánosnak és Nagy Zsoltnak a jelölés anyagául szolgáló eszközök beszerzésében történő közremúködésükért. Köszönet illeti Tóth Norbertet és Varga Sámuel Zsoltot a csapdák elkészítésében és a csapdapark kialakításában nyújtott segítségükért; a Debreceni Egyetem Böszörményi úti Campus Kertészetét a csapdázás helyszínének biztosításáért; továbbá a Nagyerdei Kultúrparkot. Köszönettel tartozunk a jelölt egyedek önkéntes visszajelzőinek: Bagi Zoltán, Bárdos Tibor, Bozsódi Dóra, Dudar Zsuzsa, Fejes Ferenc, Ferenc Viktória, Géczy Lászlóné, Godó Laura, Dr. Gyüre Péter, Juhász Orsolya, Juhász Tamás, Kiss Csilla, Dr. Kozák Lajos, Kurucz Viktória, Lendvai Ádám, Lenner Ádám, Leskó János, Leskó Jánosné, Dr. Nagy Sándor, Péter Miklós, Pinczés Sarolta, Pitó Andor, Pócsik Richárd, Polonkai László, Sándor Andrea, Sonkoly Judit, Soós Zoltán, Szarka-Kányási Viktória Éva, Szathmári Judit, Szemán Karola, Tohol Éva, Tóth Emese, Tóth Norbert, Ujvárosiné Széll Ágnes, Varga Sámuel Zsolt, Vékás József, Veszelinov Ottó, Vizi Nóra.

\section{Irodalomjegyzék}

Amar, A. \& Burthe, S. (2001): Observations of predation of Hen Harrier nestling by Hooded Crows in Orkney. - Scottish Birds 22: 65-66.

Anderies, J. M., Katti, M. \& Shochat, E. (2007): Living in the city: Resource availability, predation, and bird population dynamics in urban areas. $-J$ Theor Biol. 247: 36-49. doi: http://dx.doi.org/10.1016/j.jtbi.2007.01.030

Bub, H. (1995): Bird Trapping and Bird Banding. - Cornell University Press, Ithaca, New York, $330 \mathrm{p}$.

Caffrey, C. (2000): Marking crows. - North American Bird Bander 10: 146-150.

Curtis, P. D., Braun, C. E. \& Ryder, R. A. (1983): Wing markers: visibility, wear, and effects on survival of band-tailed pigeons. - J. Field Ornithol, 54: 351-356.

Emery, N. J. \& Clayton, N. S. (2004): The Mentality of Crows: Convergent Evolution of Intelligence in Corvids and Apes. - Science 306: 1903-1907. doi: http://dx.doi.org/10.1126/science.1098410

Fintha, I. (1994): A dolmányos varjú (Corvus cornix) életformájának átalakulása az utóbbi években. - Madártani tájékoztató 1994. júl.-dec.: 23-24.

Gremmel, A. (1988): Understanding crow damage control. - Cooperative Extension Service, Kansas State University.

Hester, A. E. (1963): A plastic wing tag for individual identification of passerine birds. - BirdBanding 34: 213-217.

Holzhaider, J. C., Sibley, M. D., Taylor, A. H., Singh, P. J., Gray, R. D. \& Hunt, G. R. (2011): The social structure of New Caledonian crows. - Anim. Behav. 81: 83-92. 
Juhász, L. (1983): Debrecen város ornithofaunájának faunisztikai és synökológiai vizsgálata. - Egyetemi doktori értekezés, KLTE, Debrecen

Juhász, L., Kövér, L. \& Gyüre P. (2009): The urbanization of the Hooded Crow (Corvus cornix L.) in Debrecen (Hungary). - II. European Congress of Conservation Biology, Prague 2009, Book of Abstracts, $227 \mathrm{p}$.

Kőszegfalvi, T. (2008): Dolmányos varjak (Corvus corone) galambvadászata. - Aquila, 114/115: 171.

Kövér, L., Gyüre, P., Balogh, P., Huettmann, F., Lengyel, Sz. \& Juhász, L. (2015): Recent colonization and nest site selection of the Hooded Crow (Corvus corone cornix L.) in an urban environment. - Landscape Urban Plan. 133: 78-86. doi: https://doi.org/10.1016/j.landurbplan.2014.09.008

Kövér, L. \& Juhász, L. (2012): A dolmányos varjú (Corvus cornix L.) színes gyürüs jelölésének módszertana és az előzetes eredmények. - Agrártudományi Közlem. 2012/48: 43-48.

Kövér, L., Tóth, N., Lengyel, Sz. \& Juhász, L. (2017): Corvid control in urban environments: a comparison of trap types. - North-West J Zool., in press.

Loretto, M. C., Reimann, S., Schuster, R., Graulich, D. \& Bugnyar, T. (2015): Shared space, individually used: spatial behaviour of non- breeding ravens (Corvus corax) close to a permanent anthropogenic food source. - J. Field Ornithol. 157: 439-450. doi: http://dx.doi.org/10.1007/s10336-015-1289-z

Mazgajski, T. D., Żmihorski, M., Halba, R. \& Woźniak A. (2008): Long-term population trends of corvids wintering in urban parks in central Poland. - Pol. J. Ecol. 56: 521-526.

Møller, A. P. (2009): Successful city dwellers: a comparative study of the ecological characteristics of urban birds in the Western Palearctic. - Oecologia 159: 849-959. doi: http://dx.doi.org/10.1007/s00442-008-1259-8

Morgenweck, R. O. \& Marshall, W. H. (1977): Wing marker for American Woodcock. - Bird-Banding 48: 224-227.

Mudge, G. P. \& Ferns P. N. (1978): Durability of patagial tags on Herring Gulls. - Ringing \& Migration 2: 42-45. doi: http://dx.doi.org/10.1080/03078698.1978.9673734

O’Donoghue, P. D., Cross, T. F. \& O'Halloran J. (1998): Bill colour as an ageing technique in the Hooded Crow Corvus corone cornix: A cautionary note. - Ringing \& Migration 19: 1-4. doi: http://dx.doi.org/10.1080/03078698.1998.9674153

Phillips, R. L., Cummings, J. L. - Berry, J. D. (1991): Effects of patagial markers on the nesting success of Golden Eagles. - Wildl. Soc. Bull. 19: 434-436.

Raatikainen, M., (1989): Variksen ja naakan talvipäivän pituus ja käyttö Jyväskylässä. - Keski Suomen Linnut, 14: 72-81.

Reading, R. P., Maude, G., Hancock, P., Kenny, D. E. \& Garbett, R. (2014): Comparing different types of patagial tags for use on vultures. - Vulture News, The Journal of the IUCN Vulture Specialist Group, 67: 33-42. doi: http://dx.doi.org/10.4314/vulnew.v65i1.3

Stiehl, R. B. (1983): A New Attachment Method for Patagial Tags. - J. Field Ornithol. 54: 326-328.

Sweeney, T. M., Fraser, J. D. \& Coleman, J. S. (1985): Further evaluation of marking methods for Black and Turkey Vultures. - J. Field Ornithol. 56: 251-257.

Tóth, L. (2006): Barna rétihéják jelölése váll-lapokkal. - Heliaca 2004: 69-70.

Vogrin, M. (2003): Common Magpie Pica pica, Western Jackdaw Corvus monedula and Hooded Crow Corvus cornix in Some Towns in North-estern Slovenia (Central Europe). - Online J. Biolog. Sci. 3: 688-693.

Vrezec, A. (2010): Historical occurrence of the Hooded/Carrion Crow (Corvus cornix/corone) in urban areas of europe with emphasis on Slovenia. - Annales Ser. Hist. Nat. 20: 131-140. 
Vuorisalo, T., Andersson, H., Hugg, T., Lahtinen, R., Laaksonen, H. \& Lehikonen, E. (2003): Urban development from an avian perspective: Causes of hooded crow (Corvus corone cornix) urbanisation in two Finnish cities. - Landscape Urban Plan. 62: 69-87. doi: https://doi.org/10.1016/ S0169-2046(02)00124-X

Wallace, M. P., Parker, P. G. \& Temple, S. A. (1980): An evaluation of patagial markers for cathartid vultures. - J. Field Ornithol. 51: 309-428.

Watson, J. W. (1985): Trapping, Marking and Radio-Monitoring Rough-Legged Hawks. - North American Bird Bander 10: 9-10.

\section{Függelék:}

A cikkhez tartozó Online Függelékek a folyóirat honlapján találhatóak.

Függelék 1: A csapdázási kísérlet során alkalmazott csapdatípusok

Függelék 2: Szárnybilétával jelölt dolmányos varjak

Függelék 3: A biléták felhelyezésének metodikája 


\title{
Marking Hooded crows (Corvus cornix L.) with wing- tags in Debrecen, Hungary
}

\author{
Petra Paládi ${ }^{1}$, Dávid Tóth ${ }^{1}$, Szabolcs Lengyel ${ }^{2}$, Lajos Juhász ${ }^{1}$ and \\ László Kövér ${ }^{1}$ \\ ${ }^{1}$ University of Debrecen, Faculty of the Agricultural and Food Sciences and \\ Environmental Management, Department of Nature Conservation, Zoology and Game \\ Management, \\ H-4032 Debrecen, Böszörményi út 138, Hungary \\ ${ }^{2}$ MTA OK, Danube Research Institute, Department of Tisza Research \\ H-4026 Debrecen, Bem tér 18/C, Hungary \\ e-mail:paladi17@gmail.com
}

The Department of Nature Conservation, Zoology and Game Management of the Faculty of Agricultural, Food Sciences and Environmental Management of the University of Debrecen has been paying attention to crows which occur in urban environment since 2006. Especially in case of the Hooded Crows (Corvus cornix L. 1758) as its significant population growth causes several problems both in urban avifauna (nest predation) and also for the human (riot, abuse, aggression). Reflecting this, it is conceivable that their urban population control is necessary, catching Hooded Crows with live traps can be a solution. The first steps began in November of 2016 when the Department carried out a trapping experiment, and examined four types of live catching corvid traps to compare them, and test their effectiveness in an urban habitat. The aim of this study was also to mark the captured birds individually, and observe their movements around the city. Thanks to this, we can learn more about their motion patterns, area fidelity and their survival. We marked Hooded Crows with white wing-tags with unique black numbers written on them. Tags were attached to the patagium with ear tags (which is used successfully on sheeps). During more than 100 trap-days we captured 28 Hooded Crows, and several Rooks (Corvus frugilegus L. 1758). Out of 28 marked Hooded Crows we obtained data about 26 individuals, this means more than 250 records. According to preliminary results the Hooded Crows are loyal to their territories, since most of the feedbacks arrived from the area of the ringing site. The longest known distance covered by a bird was $4 \mathrm{~km}$. Marked crows often move in groups, one time we counted 16 marked individuals in the same flock. Using wing-tags seems to be an effective way to mark Hooded Crows, since marked individuals are easy to spot and identify, even from greater distances, compared to birds which were only marked with coloured rings.

Keywords: Hooded Crow, Corvus cornix, urban habitat, wing-tag, patagial-tag, trapping 